Article

\title{
Perception of the Values of the Biocultural Landscape Types of Slovakia by the Population
}

\author{
Zita Izakovičová (D), Jana Špulerová * (D), Zuzana Baránková and Andrej Palaj \\ Institute of Landscape Ecology of the Slovak Academy of Sciences, 81499 Bratislava, Slovakia; \\ zita.izakovicova@savba.sk (Z.I.); zuzana.barankova@savba.sk (Z.B.); andrej.palaj@savba.sk (A.P.) \\ * Correspondence: jana.spulerova@savba.sk
}

\begin{abstract}
The perception of the landscape by society is becoming an integral part of many studies in terms of the quality of the living environment, sport and recreation and building and developing social relationships. To evaluate the perception and appreciation of individual landscape types by society, we used an online questionnaire as a form of sociological survey. We used the statistical method of non-metric multidimensional scaling NMDS in R package to determine the variability of responses in relation to respondents. The relationship between demographic factors and landscape perception and landscape type preferences was evaluated. The results of multidimensional scaling show a strong relationship between young men and a preference for recreation over agro-tourism. The middle generation with university education looks more frequently for cultural monuments. University-educated middle-aged men perceive the natural landscape as degraded and endangered, and middle-aged men with secondary education understand the need for the protection of traditional agricultural landscapes. It is important to integrate people's preferences and needs into the landscape planning and decision-making processes, so that they can contribute to the creation of development plans and other strategic documents.
\end{abstract}

Citation: Izakovičová, Z.; Špulerová, J.; Baránková, Z.; Palaj, A. Perception of the Values of the Biocultural Landscape Types of Slovakia by the Population. Land 2022, 11, 72.

https://doi.org/10.3390/land 11010072

Academic Editors:

Alexandru-Ionuţ Petrişor and

Alejandro Rescia

Received: 14 December 2021

Accepted: 30 December 2021

Published: 4 January 2022

Publisher's Note: MDPI stays neutral with regard to jurisdictional claims in published maps and institutional affiliations.

Copyright: (c) 2022 by the authors. Licensee MDPI, Basel, Switzerland. This article is an open access article distributed under the terms and conditions of the Creative Commons Attribution (CC BY) license (https:// creativecommons.org/licenses/by/ $4.0 /)$.

Keywords: biocultural landscape types; landscape perception; sociological survey; Slovakia; landscape protection; landscape management

\section{Introduction}

Landscape has a range of meanings and can be conceptualized at a range of scales [1]. Numerical landscape classifications group land units with similar characteristics into distinct landscape types (termed land classes) and have considerable potential as tools in rural land-use planning [2] because they provide a frame of reference for communication [1] To date, numerous classifications have been developed, e.g., the European Landscape Map [3], semi-complex landscape typology of the Czech Republic [4] or the Representative Geosystems of Slovakia [5] and many others.

The landscape represents a living space not only for humans but also for all living organisms, where they live in mutual interaction, and a man can be considered the principal creator of the landscape in which he resides [6]. Different landscape types have been developed over time through mutual adaptation and possibly co-evolution [7] from natural to cultural landscape types. Landscape classification and protection are also emphasized by the European Landscape Convention, signed in 2000 in Florence [8]. The participating countries are obliged to evaluate defined landscape types with regard to specific values attributed by involved subjects. According to the Convention, each of the involved countries is obliged to create conditions with the participation of the public, local and regional authorities and other members, with an interest in defining and realizing the landscape conceptions. The interaction of humans and nature creates various biocultural types of landscape that often embed high ecological and cultural values and reveal the link between nature and culture [9]. To ensure the effective protection and preservation of valuable biocultural landscape, it is necessary to involve the general public in landscape planning and 
management, since we face both the degradation and preservation of valuable landscape structures at the same time [10].

Bioculturally diverse mosaic landscapes are historically shaped by people who have developed a strong sense of fellowship and a deep attachment to their living environment or the place [11]. These practices tend to be location-specific, landscape-specific and timespecific and result in diversified cultural landscapes [12]. Unfortunately, this type of knowledge and experience is being eroded by factors that prevent people from spending time in nature. There are concerns, especially among the older generation, that the youth and the ever-growing urban population are becoming increasingly alienated from nature; therefore, the younger generation especially should have access to nature so that they stay in touch with their cultural roots [13]. As traditional and customary land systems decline, the problems of nature conservation and heritage, which are already seriously threatened, become much worse. Additionally, such landscape transformations have dramatic and often detrimental impacts on human rural communities and economies [14]. The local people and their activity, work and social and cultural potential are the main driving forces in regional development [15] and are an important source of knowledge about the sustainable utilization of the landscape, especially in the areas with preserved traditional farming and agrarian landforms (e.g., terraces) that serve as witnesses of the traditional land use and lifestyle of former generations [16]. The conservation of species and cultivars as well as cultural heritage objects may also contribute significantly towards the maintenance of the cultural identity and personal well-being of local and indigenous communities [12].

Monitoring programs often use remote sensing data and map-derived indicators of landscape and correlation with visual landscape preferences $[17,18]$ or GIS-based scenic quality modeling using empirical data gathered through online visual landscape assessment surveys [19]. The perception of the landscape can lead to greater involvement of the civic, academic and business sectors, from which the country as a living space for every human can benefit, and consequently the whole society as well. The perception of the landscape by society is important in terms of the quality of the living environment and in terms of society's needs for housing, services, recreation, building/developing social relationships and many others. It is important to include the knowledge of these needs and preferences into the landscape planning and into the other strategic documents, such as regional development programs, tourism development strategies, management plans for the protection of natural and cultural and biocultural heritage.

The aim of this paper was to discern, (1) how the Slovak population perceives the values of the various landscape types, (2) the extent to which people perceive and are aware of the values of the biocultural landscape and (3) whether they perceive the need to protect certain types of biocultural landscapes. The results can be used in landscape management and in proposals of measures to preserve the valuable biocultural types of landscape.

\section{Methods}

\subsection{Sociological Survey}

To evaluate the perception and appreciation of individual landscape types by society, we used a sociological survey-an online questionnaire (Attachment I). We used the national thematic networks that Institute of Landscape Ecology has been building for several years (SEKOS - Slovak Ecological Society, SK IALE-International Association of Landscape Ecology) to inform and request participation in the sociological survey. Through these networks, we also addressed the general public with the invitation to participate in the survey. Except for basic demographic questions, the questionnaire contained 5 questions aimed at identifying representative landscape types of Slovakia, the perception of the state of degradation and the need to protect individual landscape types, as well as type preferences for housing and recreation. Respondents used a five-point scale (1 point-low value to 5 point-high value) for evaluation. The photographs were used to visualize individual landscape types in the questionnaire (Figure 1). 

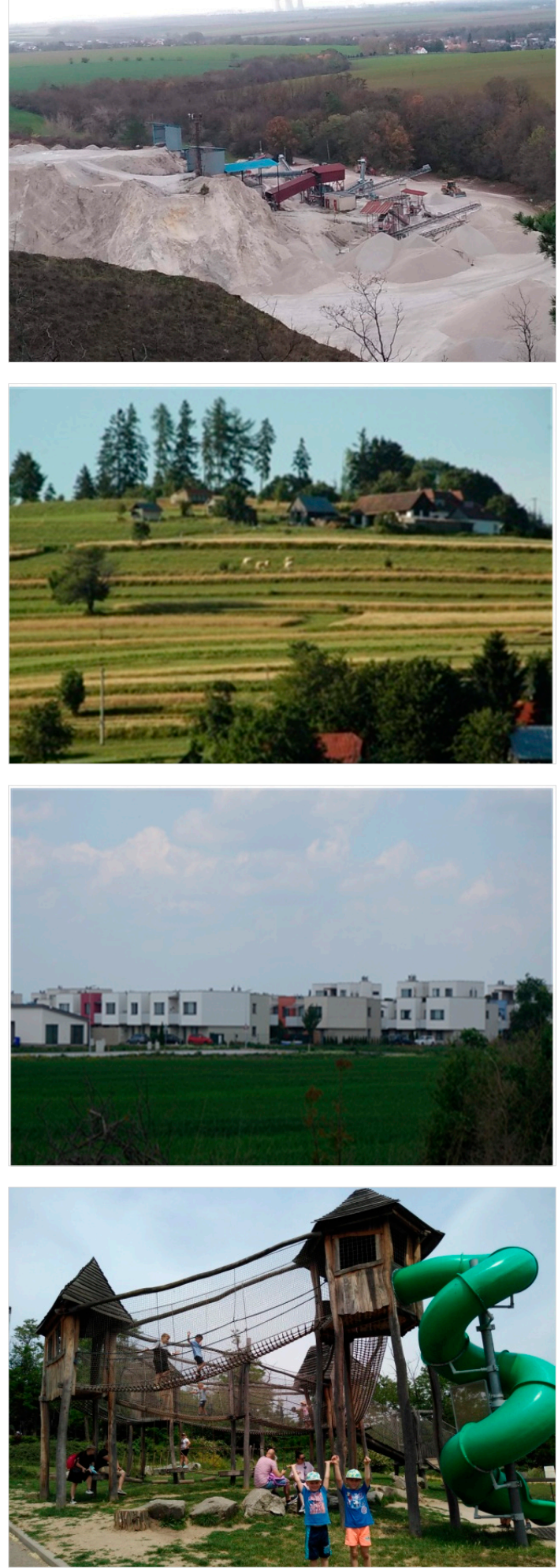
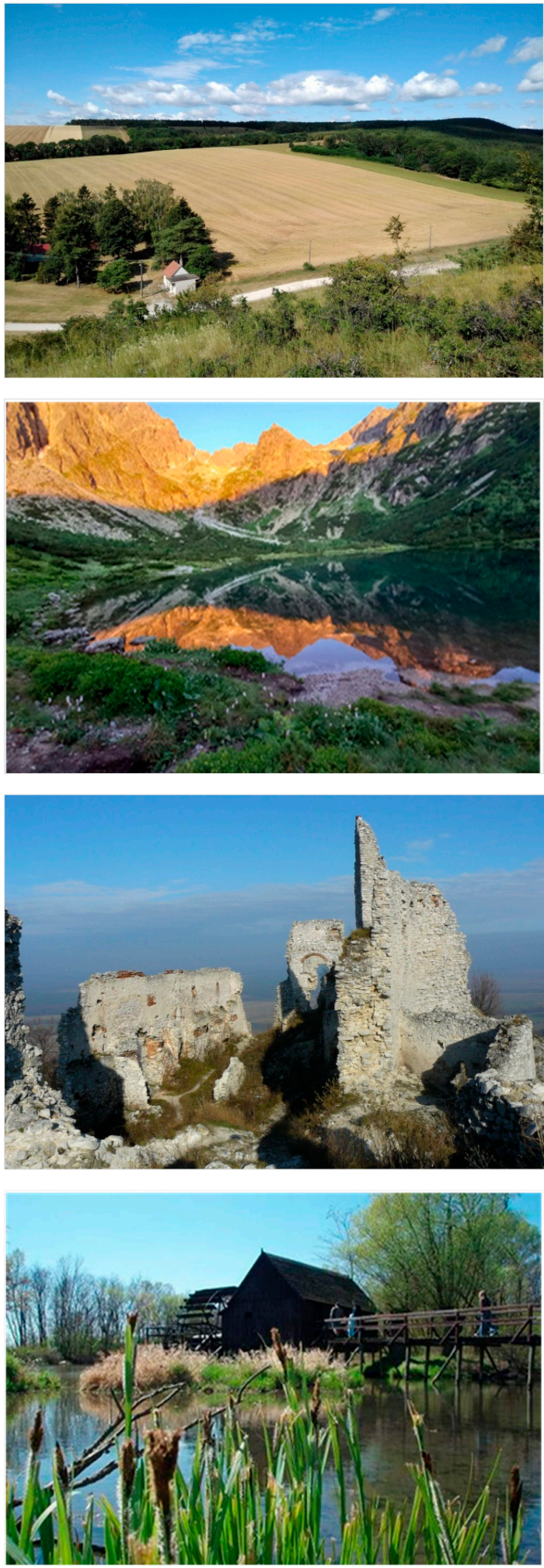

Figure 1. Landscape type and subtypes in Slovakia (Industrial mining landscape-Dolný Lopašov, 2020, Author: J. Špulerová; rural, agricultural landscape-Dolný Lopašov, 2020, Author: J. Špulerová; extensively used forest-agricultural landscape-Detvianske lazy, 2015, Author: J. Špulerová; natural mountain landscape-High Tatras, 2021, Author: V. Piscová; new constructed suburban area-Trnava region, 2017, Author: Z. Izakovičová; cultural monuments-Plavečské Podhradie, 2012, Author: J. Špulerová; amusement park-Zoo Park Bratislava, 2021, Author: J. Špulerová; historic landscape with watermills-Tomášikovo, 2008, Author: J. Špulerová). 
Based on the current study of landscape typology and knowledge of valuable landscape types [20-23], we have identified four main landscape types characteristic of Slovakia (industrial and settlement landscape; rural, agricultural landscape; extensively used forest and agricultural landscape; natural mountain landscape; other suggestion by participants), including 12 subtypes specifying biocultural landscapes.

A total of 189 respondents participated in the sociological research. Women had a slight predominance, accounting for $57.6 \%$ of participants. In terms of age the dominant group was the population aged 40-60, who represented up to more than half of the respondents. The involvement of young people was lower, with a participation rate of $18.25 \%$. According to the level of education, university-educated respondents predominated in the sociological survey ( $80.9 \%$ of all respondents). The increased representation of this age group could also be caused by the form of questionnaire distribution. The low proportion of participants with primary education $(1.7 \%)$ might be due to the fact that these residents have lower computer skills and often limited access to the internet, where the questionnaire was available for participation. Due to an unrepresentative sample, primary and secondary education were merged in further analyzes. In terms of the employment structure (Figure 2), most respondents were employed in education and science, which makes sense, as these respondents are significantly concerned with the issue. People working in services and local government offices, for whom the landscape typology is important both in terms of attractiveness and in terms of management/protection of these valuable landscape structures, also had the significant representation.

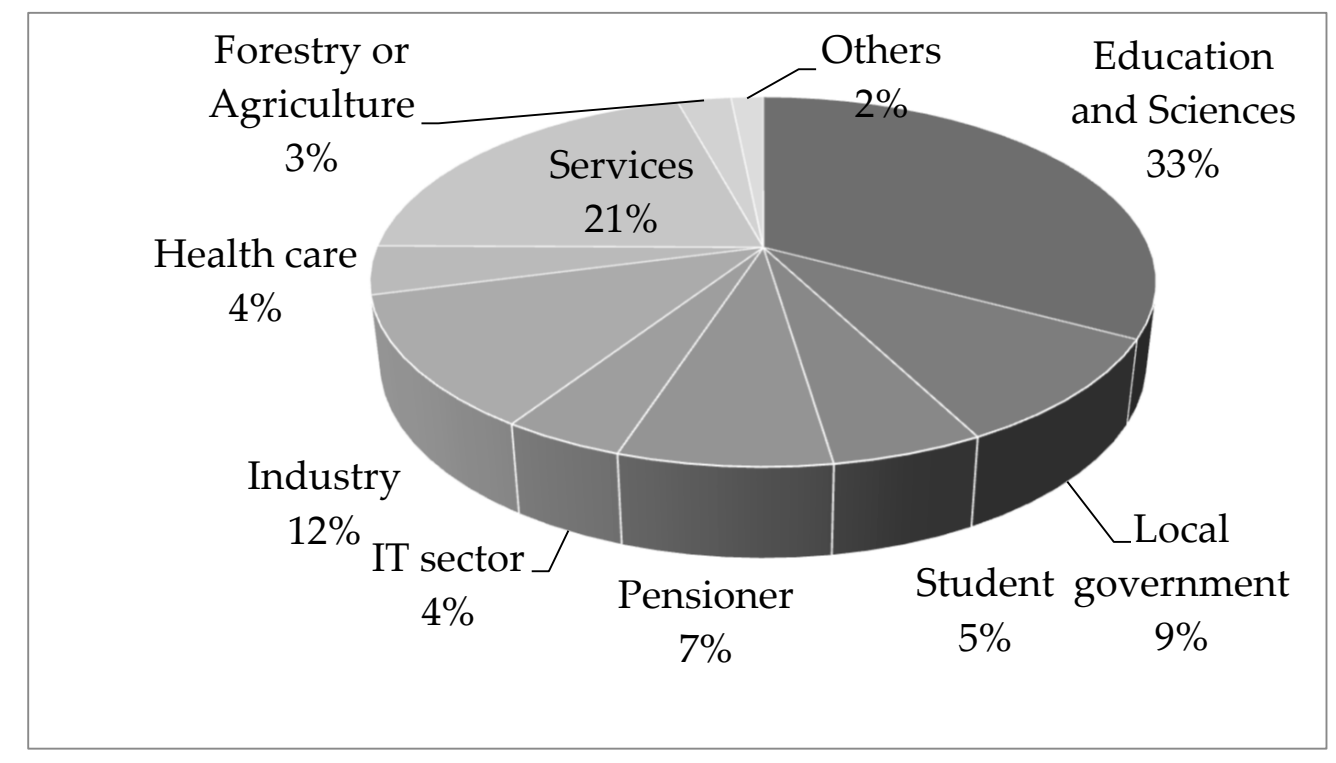

Figure 2. Respondent structure according to employment.

\subsection{Ordination Methods}

We used the method of non-metric multidimensional scaling NMDS in R package vegan $[24,25]$ to determine the variability of responses in relation to the respondents. For landscape type's data, in order to find out the preferences of the respondents, we included 3 questions in the survey: (1) Which type of landscape do you prefer for recreation or relaxation? (2) Which type of biocultural landscape would deserve the highest protection? (3) Which types of biocultural landscape do you find the most endangered/degraded? Four respondents with incomplete answers were omitted from the analyzed data set. We allowed the algorithm to draw an ordinate in three dimensions $(\mathrm{k}=3)$ to reduce the stress value below 0.1 . Finally, we used the envfit function to fit environmental factors onto an ordination. The subject sample of this study varied in (i) the gender of the respondents, (ii) age of the respondents and (iii) the highest level of education achieved. The arrows point to the direction of the gradient and the length of the arrows is proportional to the 
correlation between the ordination (preferences of the respondents) and environmental factors (gender, age and education).

\subsection{Study Area}

Slovakia is a small but relatively diversified country. The total area is $49,034 \mathrm{~km}^{2}$. The population is $5,460,136$ [26], of which $48.8 \%$ are men and $51.2 \%$ are women. The population density is 111.2 inhabitants $/ \mathrm{km}^{2}$. Slovakia is made up of two basic geomorphologic units belonging to the Alpine-Himalayan system: the Carpathians and the Pannonia Basin. Natural conditions are a determinant of the diversity of ecosystems as well as the diversity of land uses. The agricultural land dominates in the landscape structure with a share of $48.5 \%$, of which $59.17 \%$ is cultivated. Cereals are grown in particular, and the share of energy crops has been rising in recent years due to their favorable market conditions. Permanent grasslands occupy $35.8 \%$ of the area of agricultural land in the Slovak Republic, the rest are permanent crops-orchards, gardens and vineyards. The second most significant element of the landscape structure is forests, which account for $41.3 \%$ of Slovakia's area.

A total of 126 representative landscape types were identified in Slovakia [5]. Mountain types occupy the largest proportion of Slovakia (53\% of the land area). Lowland types of land occupy $29 \%$. Basin types of landscape have the smallest area $(18 \%)$. Some types of natural landscape have been significantly transformed by humans, or even degraded, but several rare landscape types with significant biocultural value have been created by the interaction of nature and man. The most important biocultural landscape types in Slovakia include traditional agricultural landscapes (meadow or pasture, wine-growing, mosaic types of agricultural landscape, landscape types with dispersed settlements) and urbanized urban and rural landscape with historical green infrastructure [27,28] (Figure 3). At present, the area of these rare biocultural types is less than $3 \%$ and is constantly declining, as they are under several pressures [29].

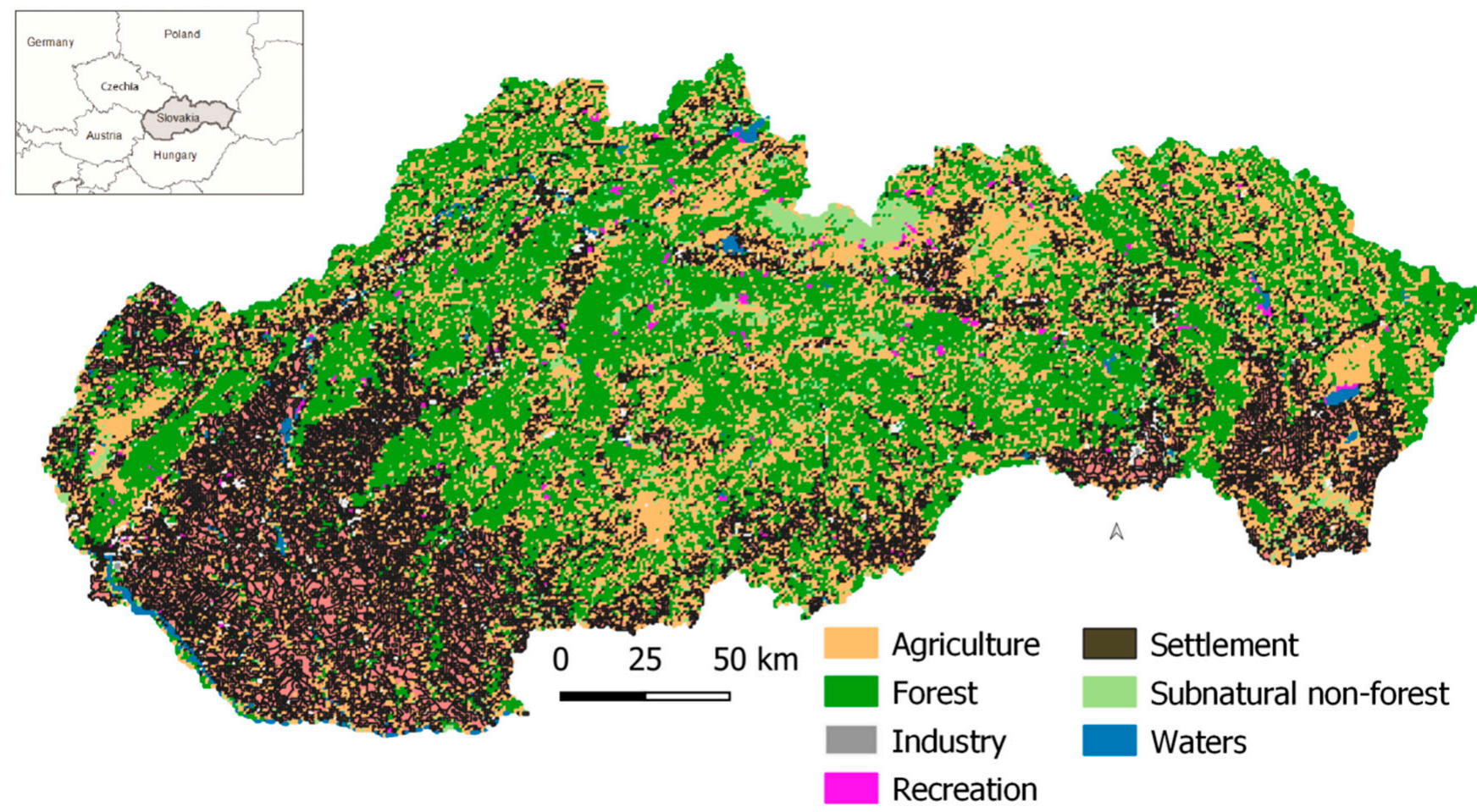

Figure 3. Study area of Slovakia-the main land use. 


\section{Results}

The results of the sociological survey were evaluated in three sessions: (1). Perception of the character of the Slovak country; (2). preferences for the use of landscape types for housing and recreation; and (3). degradation and the need to protect landscape types.

\subsection{Perception of the Character of the Slovak Country}

The results of our questionnaire survey show that $47.1 \%$ of respondents considered rural and agricultural landscape to be a characteristic Slovak landscape (Figure 4). A total of $30.1 \%$ of respondents perceived the extensively used forest and agricultural landscape, including semi-natural non-forest habitats such as scrubland, meadows, pastures, wetlands and rocks to be characteristic. A total of $5.8 \%$ of respondents perceived the natural mountain landscape as characteristic, and a relatively high proportion of respondents $(13.2 \%)$ voted for the industrial and urbanized land as a representative type of Slovakia, which may be due to the rapidly growing, developing industrial production in the post-transformation period.

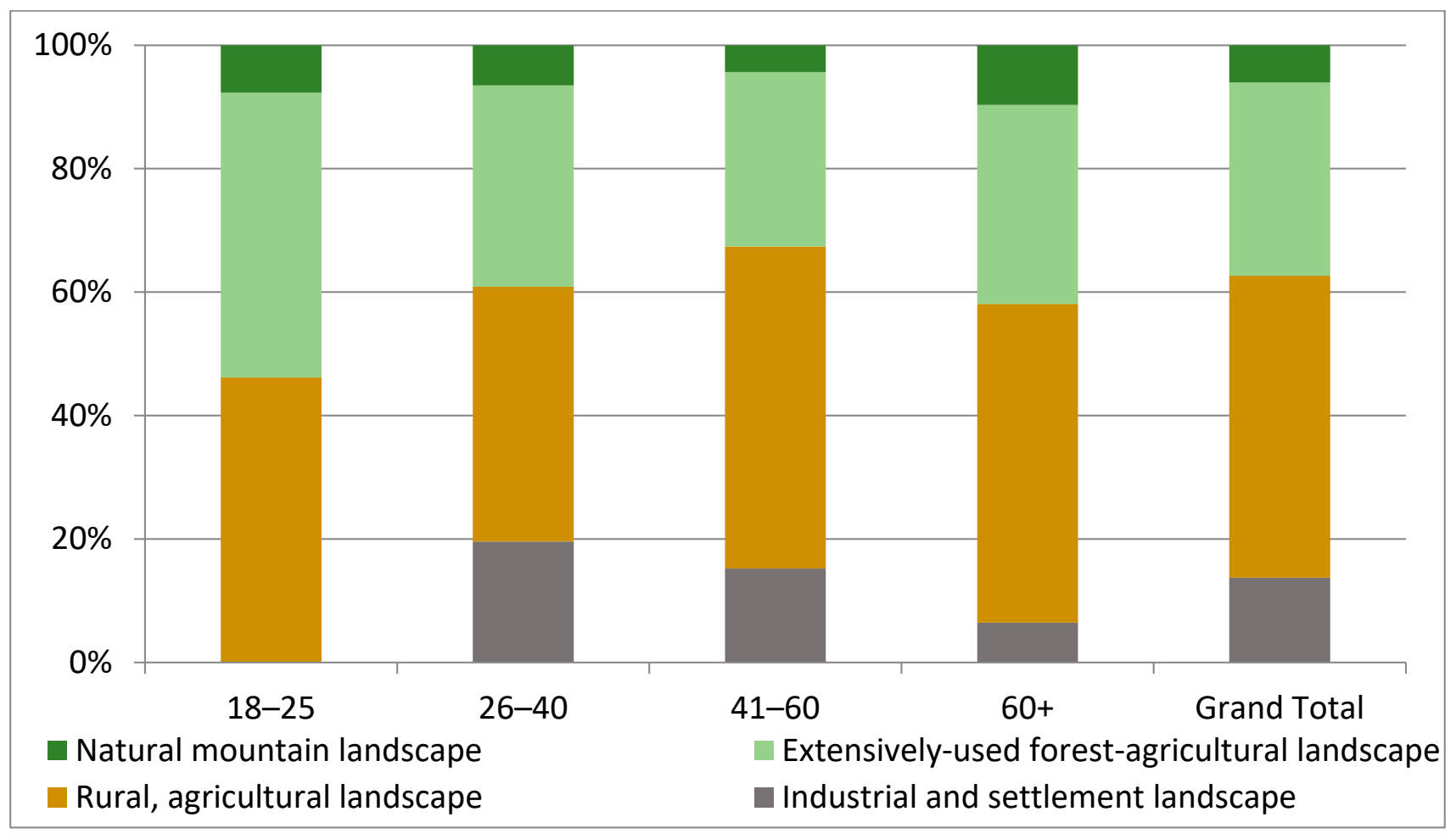

Figure 4. Specification of the most characteristic types of Slovak landscape according to the age of respondents.

After the fall of communism and the splitting of Czechoslovakia, a significant part of industrial production went bankrupt, and subsequently, political tools were created to transform and revive industry associated with the massive construction of industrial plants, industrial parks and logistics centers, which resulted in the increased anthropization of land and in particular, setting it aside. An accompanying phenomenon was also the development of housing construction in the rural environment, especially in suburban settlements close to larger cities with good access to industrial parks. A comparison of the results of the sociological survey and the current land use shows a relatively high correlation. The respondents' perception of the characteristic type of country is largely in line with the current landscape structure of Slovakia. 


\subsection{Preferences for the Use of Landscape Types for Housing and Recreation}

The respondents living in a family house, whether in an urban or rural settlement, slightly predominated (Figure 5a). In terms of housing, the respondents preferred housing in rural areas, preferably in suburban rural settlements (Figure $5 b$ ), which began to develop significantly after the transformation. On the one hand, residents preferred living close to nature, and on the other hand, they wanted certain comforts-easy access to work, close availability to services, etc. This makes the suburban rural settlements the most attractive. Housing in dispersed settlements, which are more distant and more difficult to access, was less preferred. These locations are more interesting for seasonal living or recreation. Many dwellings in these localities have recently changed into cottages and weekend houses [30]. Only $14.3 \%$ of respondents preferred living in cities.

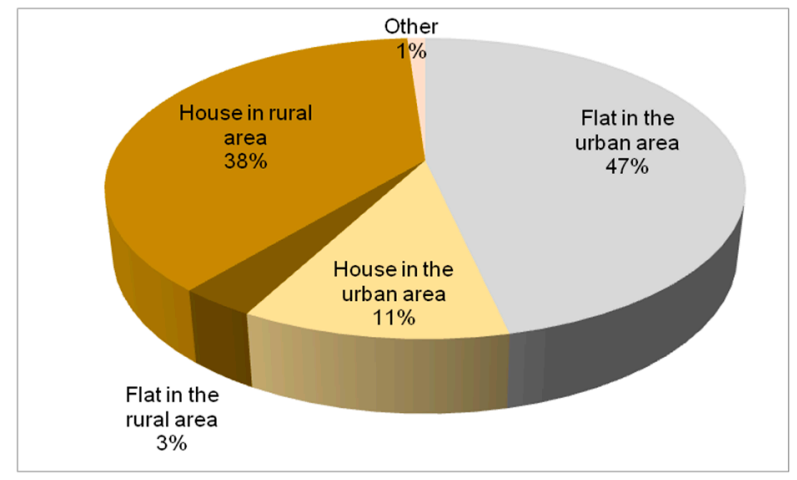

(a)

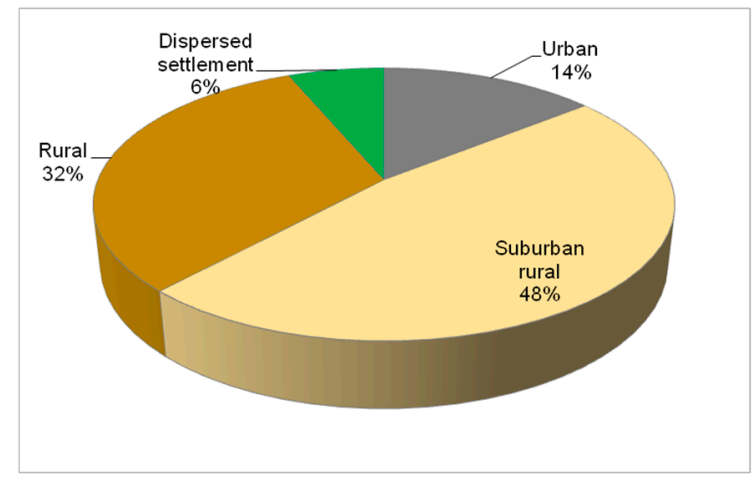

(b)

Figure 5. The landscape preference for housing: (a) current status of living and (b) landscape preference, or where they would like to live.

Respondents clearly identified natural landscape types as the most attractive type for recreation; more than $90 \%$ of respondents' assigned them third and higher levels of significance (Figure 6). In terms of recreational opportunities, the respondents also highly rated the landscape with the occurrence of cultural monuments or rural landscape types suitable for agro-tourism. Surprisingly, the respondents assigned the lowest value in terms of recreational use to land with modern attractions, such as water parks, golf courses, etc., which negatively affect the landscape scenery. This observation is probably conditioned by the sample of respondents, as the middle class of society was mostly involved in the survey, and there was little interest in survey participation from respondents in the business sector. The results of multidimensional scaling showed a strong relationship between young women (age 18-25) and a preference towards recreation for agro-tourism. The middle generation (age 41-60) with university education was looking more frequently for cultural monuments (Figure 7).

\subsection{Degradation and the Need to Protect Landscape Types}

The other two questions were focused on the respondent's assessment of perceived threats as well as the needs of protection of individual landscape types. From the respondents' point of view, the most disturbed and degraded landscape is the industrial and urbanized landscape, which is characterized by a high degree of anthropization (Figure 8). Respondents also considered the mining landscape as degraded, with which the creation of various anthropogenic forms of relief is connected, such as abandoned quarries, tunnels, heaps, dumps, etc. These forms of relief often significantly threaten the aesthetic value of the landscape. These are mainly remnants of old mining activities in Slovakia. Currently, mining activity in Slovakia is in considerable decline. However, from this abandonment, in some localities new ecosystems have been created, and they provide new habitats interesting for some endangered species of fauna and flora- e.g., rocky habitats with several thermopile species, or even habitats for many species of animals. According to more than 
$70 \%$ of respondents ( $3-5$ degree of threat), the natural mountain landscapes are endangered or degraded. At present, these types of landscape are often part of the national network of protected areas, and their protection in the Slovak Republic is already provided by the Nature and Landscape Protection Act. However, according to respondents, it is not sufficient. The results of multidimensional scaling show that pilgrimage places were considered by older women (age 60+) to be the most endangered. This is a reflection of the religion structure of the Slovak inhabitants. University-educated men aged $26-40$ perceived the natural landscape as degraded and endangered (Figure 9).

The need for protection was focused mostly on biocultural landscape subtypes. The respondents perceived a high need for protection of the traditional agricultural types of the country, which represent the most important biocultural types of the Slovak country (Figure 10). These are the following types of traditional agricultural landscapes: (1) traditional agricultural landscape (mosaics of arable land, grasslands, orchards and trees, preserved agrarian landforms); (2) traditional meadow-pasture landscape; and (3) traditional wine-growing landscape.

Regarding the cultural landscape types, the respondents indicated the protection of cultural monuments in settlements, whether urban or rural, as those which need higher level of protection (placed on the third to fifth levels within the five-level scale); this was indicated by $92.6 \%$ respondents. Respondents described the lowest need for the protection of industrial landscape, which is to a large extent a fundamental factor threatening and degrading other types of landscapes. The results of multidimensional scaling showed that men with secondary education, aged $26-40$, perceived the need for the protection of traditional agricultural and wine-growing landscape (Figure 11).

A positive result of the sociological survey is that, in addition to scientists, the general public also highly values natural and semi-natural landscape types and perceives problems with threats and insufficient protection. In terms of preserving these valuable landscape structures, it is necessary to embrace this public interest in the practical management and protection of biocultural values of the Slovak country.

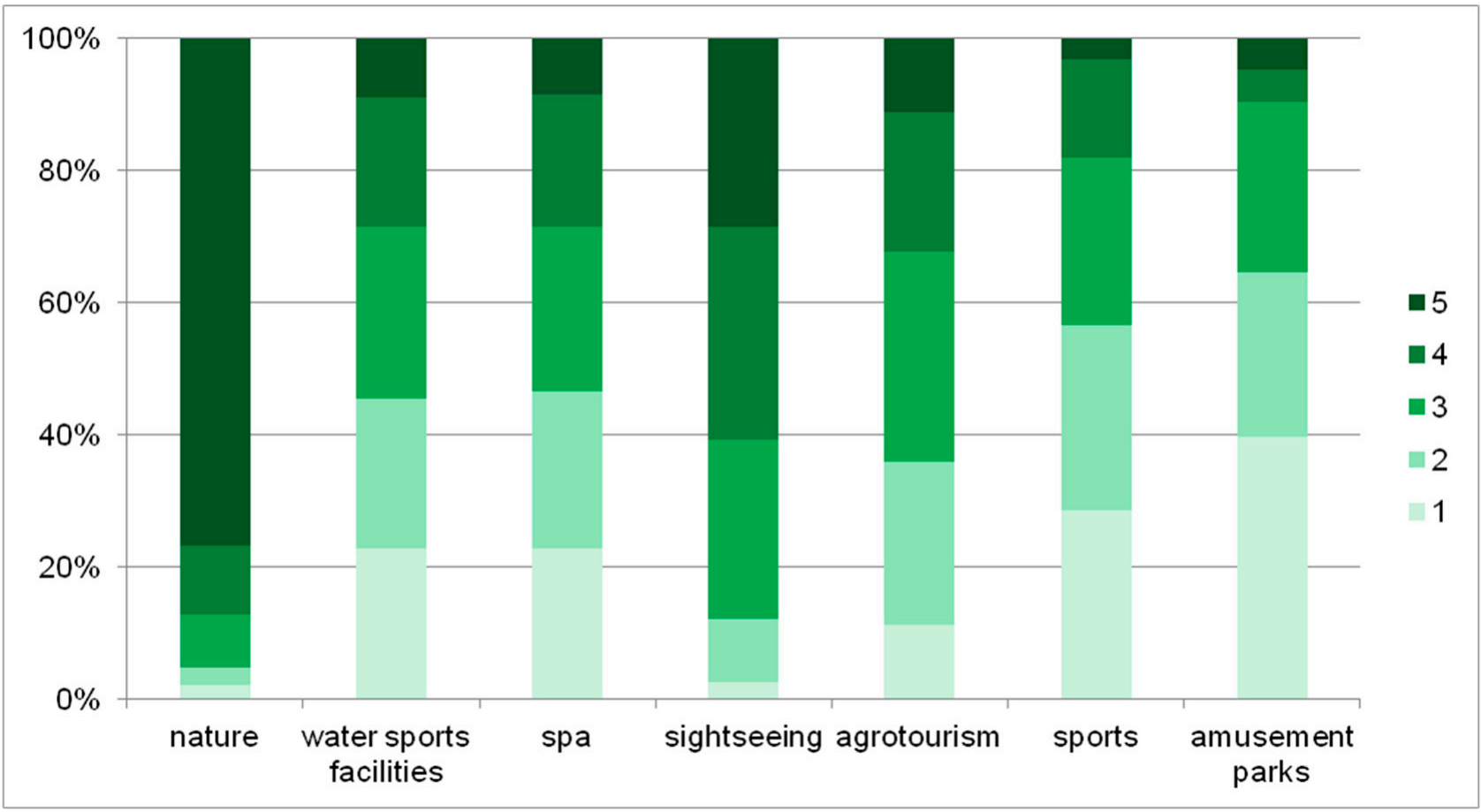

Figure 6. Preference of landscape types for recreation and relaxing (1-less interesting to 5-the most interesting). 


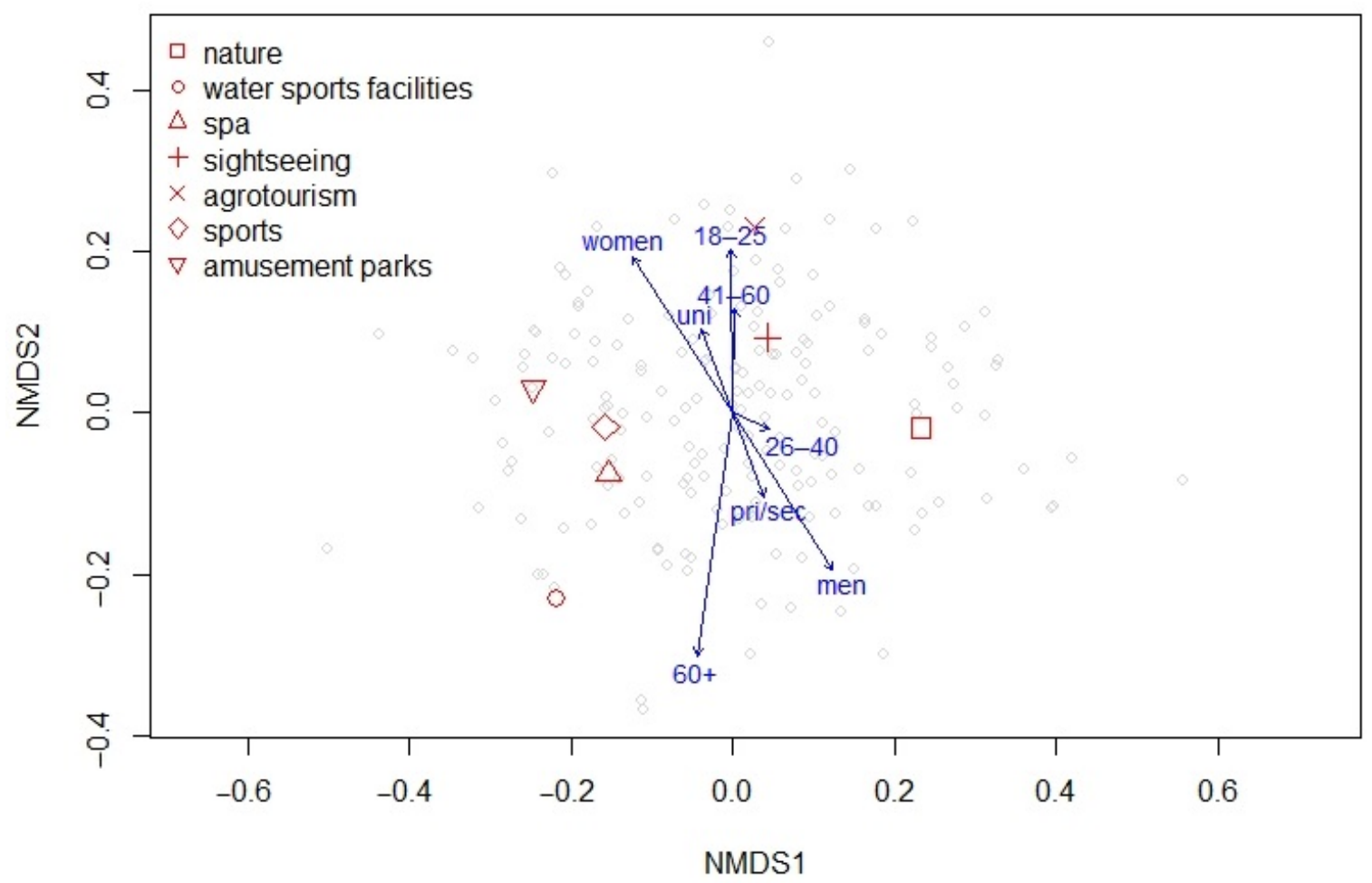

Figure 7. Multidimensional scaling of preference landscape for recreation by respondents (uni-university education; pri/sec-primary and secondary education).

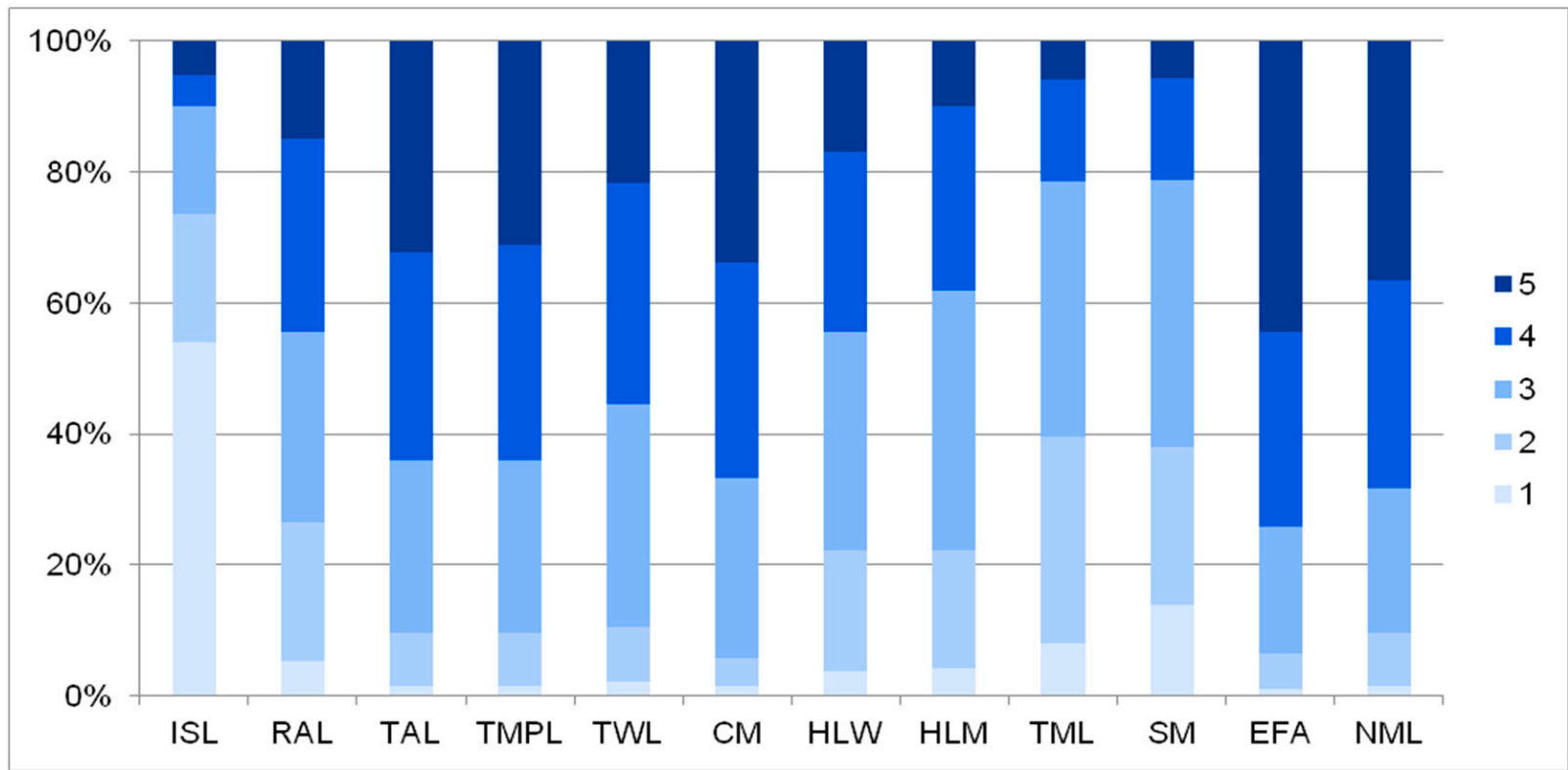

Figure 8. Which types of landscape do you find the most endangered/degraded? (Legend: 5-Under the greatest threat, 1-Under the least threat; landscape subtypes: ISL-Industrial and settlement landscape; RAL—Rural, agricultural landscape; TAL—Traditional agricultural landscape; TMPL-Traditional meadow and pasture landscape; TWL—Traditional wine-growing landscape; CM-Cultural monuments in settlements; HLW-Historic landscape with watermills; HLM-Historical landscape of mixed type; TML—Traditional mining landscape; SM-Sacred monuments; EFA-Extensively used forest-agricultural landscape; NML-Natural mountain landscape). 


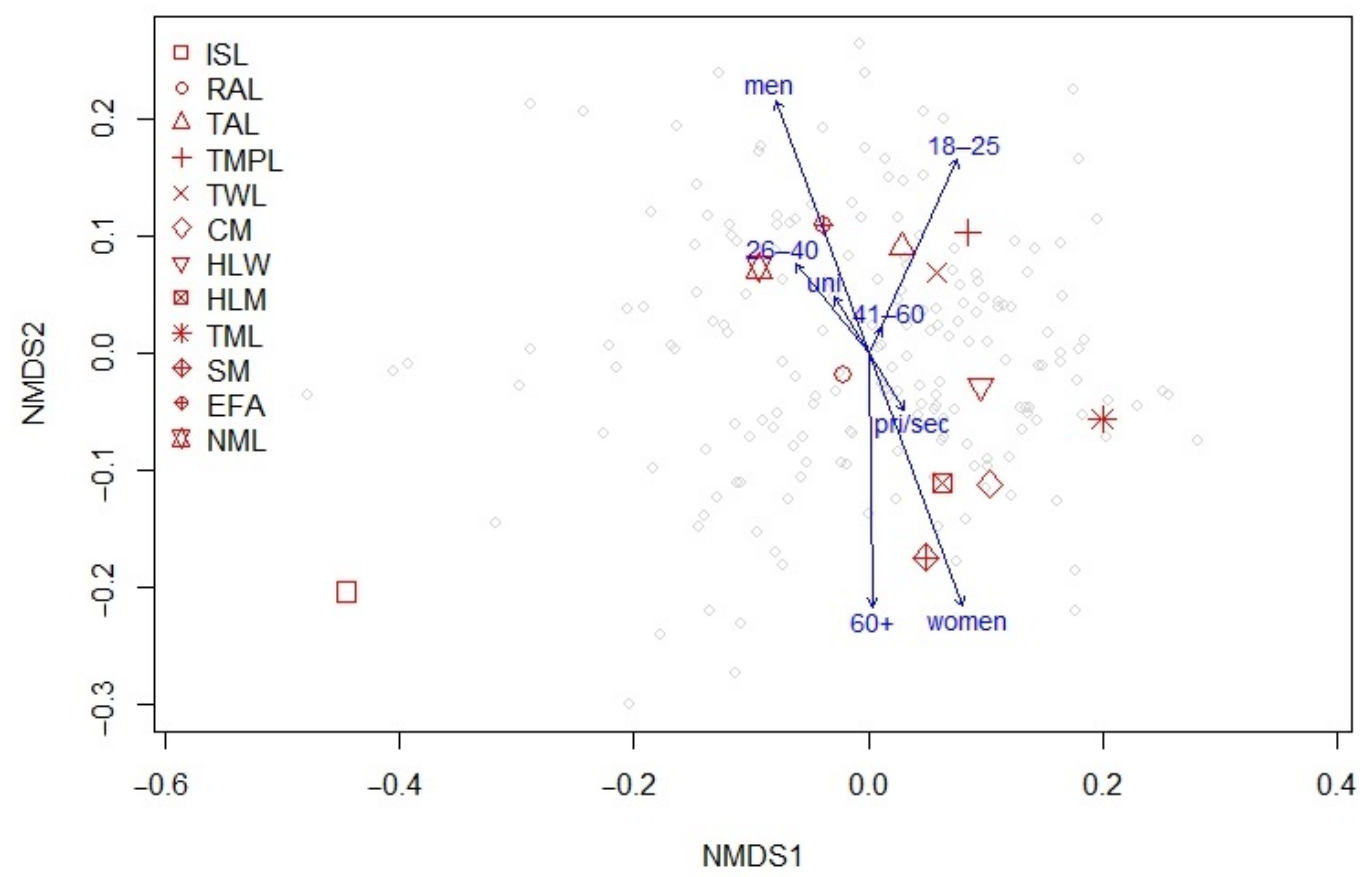

Figure 9. Multidimensional scaling of respondent perceptions of landscape that they find the most endangered/degraded (Variability and preferences of respondents: uni-university education; pri/sec-primary and secondary education; Gender: women, men; Age categories: 18-25; 26-40, 41-60, 60+; Landscape types: ISL-Industrial and settlement landscape; RAL—Rural, agricultural landscape; TAL—Traditional agricultural landscape; TMPL-Traditional meadow and pasture landscape; TWL-Traditional wine-growing landscape; CM-Cultural monuments in settlements; HLW-Historic landscape with watermills; HLM-Historical landscape of mixed type; TML_-Traditional mining landscape; SM-Sacred monuments; EFA—Extensively used forest and agricultural landscape; NML-Natural mountain landscape).

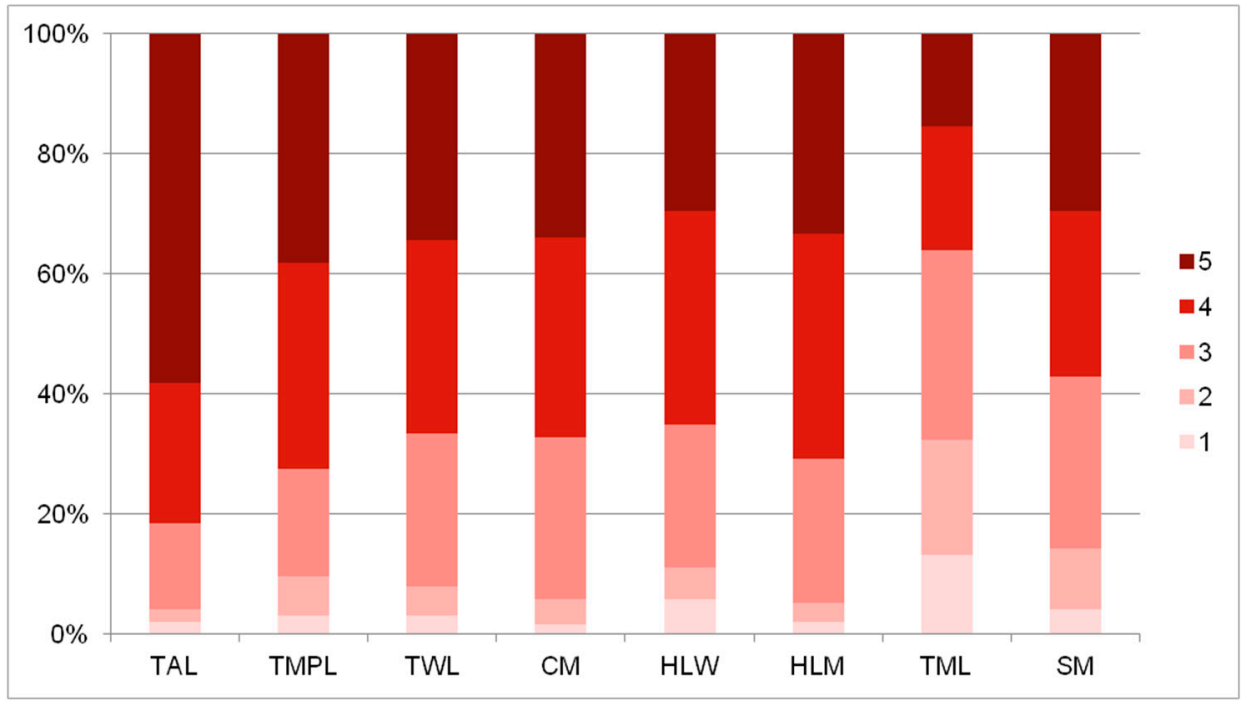

Figure 10. The need for landscape protection-Which types of biocultural landscape do you find the most endangered/degraded and in need of the most protection? (Legend: 5-the highest protection needed, 1-the least protection needed. Biocultural landscape subtypes: TAL-Traditional agricultural landscape; TMPL-Traditional meadow and pasture landscape; TWL-Traditional wine-growing landscape; CM-Cultural monuments in settlements; HLW-Historic landscape with watermills; HLM-Historical landscape of mixed type; TML_Traditional mining landscape; SM-Sacred monuments). 


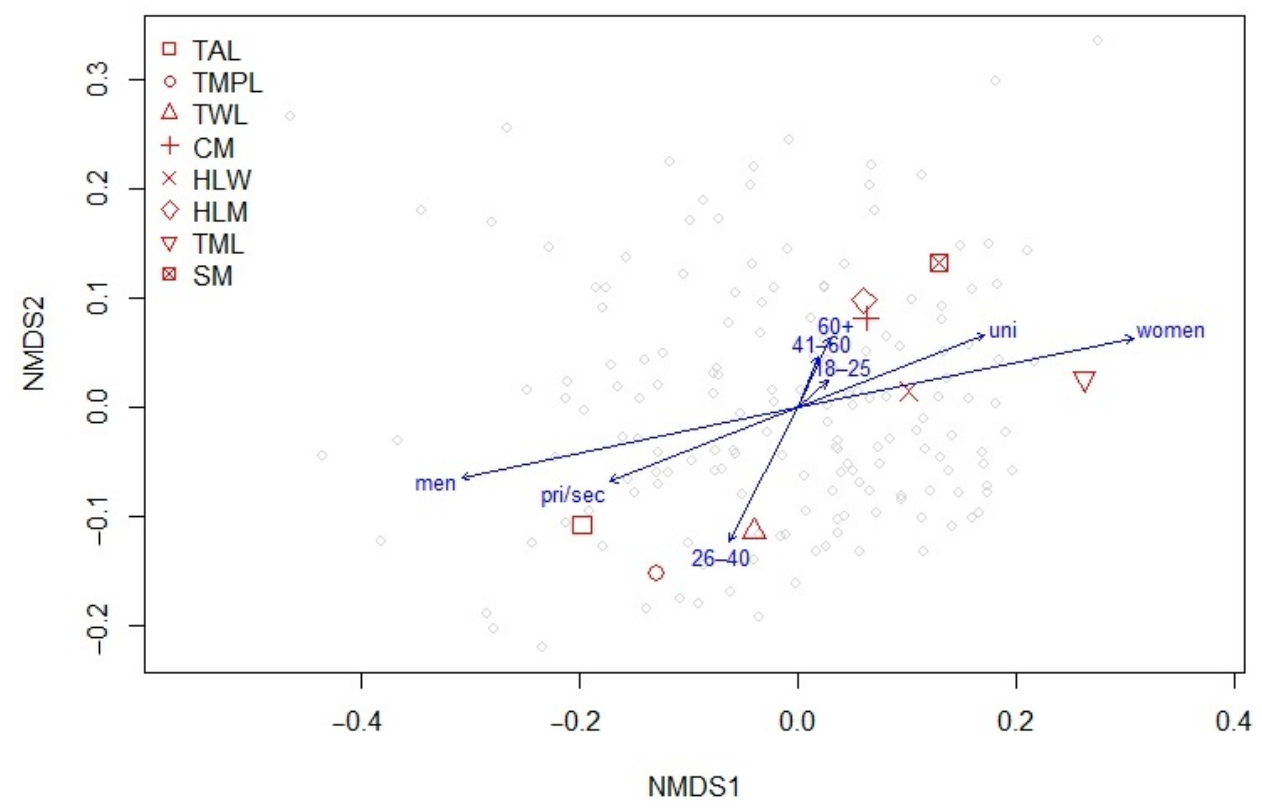

Figure 11. Multidimensional scaling of respondent perceptions on biocultural landscapes that need protection (Variability and preferences of respondents: uni-university education; pri/sec-primary and secondary education; gender: women, men, Age categories: 18-25; 26-40, 41-60, 60+; biocultural landscape types: TAL-Traditional agricultural landscape; TMPL-Traditional meadow and pasture landscape; TWL-Traditional wine-growing landscape; $\mathrm{CM}$-Cultural monuments in settlements; HLW-Historic landscape with watermills; HLM-Historical landscape of mixed type; TML_Traditional mining landscape; SM—Sacred monuments).

\section{Discussion}

Public opinion tools provide useful information on the state of perception on different topics. Results of sociological surveys and public opinion tools within the EU and Slovakia indicate a relatively strong opinion towards the environment and nature protection agenda in the public debate [31]. The issue of the future of nature and landscape is addressed in various international-level assessment reports, which are largely alarming and point to unsustainable developments in biodiversity and the state of the environment, e.g., a global assessment report on biodiversity and ecosystem services from the Intergovernmental Science-Policy Platform on Biodiversity and Ecosystem Services [32], and the European environment-state and outlook 2020 [33], an IPCC Special Report on the Impacts of Global Warming [34], Agenda 2030 [35]. As a basic approach to trend analysis in strategic planning, it is a matter of the most comprehensive understanding of the current situation and extrapolation of trends, while considering strong and weak signals and considering few likely but possible alternatives (opportunities and threats). The response to the development of the current state are various strategic documents focused on the improvement situation, e.g., A European Green Deal [36], EU Biodiversity Strategy for 2030 [37], The Farm to Fork Strategy [38] and Agenda 2030 [35].

In the European Union, $80 \%$ of all citizens live in urban areas. Cities currently face several environmental issues that most affect the health of the population, such as air pollution, high traffic density, noise, waste and wastewater production, etc. Despite the preference of the urban environment over the rural, we observed a slight decline in the urban population in Slovakia from $56.9 \%$ in 2000 to $53.3 \%$ in 2020 [26], especially near the big cities. The results of our survey confirm that suburban rural settlements are the most attractive for housing and living. On the other hand, nature is the most popular landscape for recreation. In general, citizens value forests and other green spaces positively; however, valuations of different levels of plant diversity vary significantly between cities, suggesting that the regional context and, moreover, cultural factors, matter in the relationships between people and urban nature [39]. The evaluation of the aesthetic 
values of various landscape types in Slovakia by the method of geolocated photographs from Google Panoramio showed that the most visually appreciated landscapes are the subalpine and alpine landscape types, followed by attractive urban landscapes and a less intense type of rural landscape [40]. An interesting finding from an extensive survey of the general public attitude on the perception and evaluation of nature in nine EU Member States, including Slovakia [41,42], is that the vast majority of European citizens value nature for its intrinsic value (60\%). Only $25 \%$ of respondents supported the anthropocentric point of view that nature should meet human needs rather than remain natural. The survey also showed that young people, people with a university degree and urban citizens identify more with the idea of the intrinsic value of nature compared to the older generation, people with a lower education and the rural population, which is consistent with our results.

Local people in our survey perceived the main threat to disappearing traditional agricultural landscape already existing pressures on the landscape that are not directly subject to nature protection or to cultural heritage protection. Biocultural landscapes have been studied in relationship with the indigenous communities that have been widely recognized to be the most sustainable societies on the planet [43]. The biocultural diversity of rural areas in modern countries is the focus of researchers mainly targeting the traditional agricultural landscape. The perception of valuable landscapes by local people and farmers was studied by several authors $[16,44,45]$. The housing sprawl is the main threat to the traditional agricultural landscape in Slovakia, which lies in the vicinity of big cities $[16,46]$. The main threat to traditionally managed farmland is the abandonment of agricultural land conditioned by the high migration of young people to cities and their lack of interest in farming. The abandonment of traditional farmland, including agrarian landforms such as terraced fields goes hand in hand with higher management expenses due to the small-scale structure of fields and less favorable relief conditions. This type of farming is not able to compete with conventional agriculture and struggles to survive without subsidies. Some areas are under pressure due to non-regulated tourism in mountain tourist settlements. Another problem is the extinction of picturesque small-block vineyards, which are declining mainly due to worsening socio-economic conditions, difficult farming, high costs and low profits.

Biocultural diversity has been recently also applied in urbanized and industrialized societies, in particular for the planning and management of urban green infrastructure [47-49]. The structurally diverse parks enhance motivation to be out in nature and increase overall enjoyments of the environment [49]. People largely prefer higher plant species richness in urban green spaces (i.e., parks, wastelands, streetscapes) and agree that higher plant species richness enables better life in cities [39]. EU citizens' surveys have shown a public demand for activities to improve the state of the environment [31]. In this context, mobilizing the public to support better environmental policies and practices, including nature scenarios, can also serve to strengthen public debate.

The scenarios offer a platform for discussion between interest groups and/or disciplines [50]. Regarding Slovakia, this scenario approach was used for the scenario development in the environment 2020+ study [51], or Nature Outlook [52]. A normative, anticipatory scenario begins with a defined, shared or desired vision of the future (this can be defined as a strategy or policy goal) and then works back in time to document and analyze the necessary steps to achieve the goal, as well as to define the threats. The results of our survey highlight the different landscape types, especially biocultural subtypes that people value or those that are most at risk, in order to take appropriate measures to maintain them.

\section{Conclusions}

Respondents in the sociological survey confirmed that they highly rate and value natural and semi-natural landscape types, which are important not only in terms of biodiversity protection but also from a cultural-historical and aesthetic point of view. They emphasized the need to protect these valuable landscapes and pointed out that increased attention 
should be paid to traditional agricultural landscapes, which are currently threatened by the lack of agricultural management leading to abandonment and have insufficient protection. As there is not an ensured higher level of landscape protection for these places, e.g., construction activities often spread and are often not in accordance with traditional architecture.

Some elements may be separately and partially protected as biodiversity or culturalhistorical sites, but that is not sufficient for the effective protection and preservation of these landscape structures. If we want to ensure the protection of these valuable biocultural landscape types, as declared in the European Landscape Convention, it is necessary to establish categories for the protection of valuable landscape structures in the form of a protected landscape element. Slovakia has a great chance to do so, as the Law of Nature and Landscape Protection is being amended here, and a country law is also being prepared. If we really want to preserve these valuable landscape structures, financial support for farming in these areas should be more appropriately set up in the new rural development program of 2023-2027. Through the implementation of interventions, reflecting the smallscale mosaic structure of these high-nature-value farmlands and less favored conditions for management, there is a chance to garner real support for these valuable landscapes. Because residents perceive these problems, they can be effectively involved in protecting valuable biocultural types of landscape. Involving stakeholders in the planning and decision-making processes is also very important, so that they can contribute to the creation of development plans, identify with the proposals and show interest in developing and managing the planned measures.

Supplementary Materials: The following supporting information can be downloaded at: https: / / www.mdpi.com/article/10.3390/land11010072/s1. An questionnaire, which we used to for an online sociological survey is available at Attachment I.

Author Contributions: Conceptualization, Z.I. and J.Š.; methodology, Z.I. and A.P.; writing-original draft preparation, Z.I., Z.B., J.Š.; visualization, A.P. and J.Š. All authors have read and agreed to the published version of the manuscript.

Funding: This work was supported by the Scientific Grant Agency of the Ministry of Education of the Slovak Republic [No. 2/0078/18 "Research of biocultural values of landscape"].

Institutional Review Board Statement: Not applicable.

Informed Consent Statement: The questionnaire survey was anonymous, informed consent was obtained from all participant involved in the survey to use their responses for research purposes.

Data Availability Statement: The data presented in this study are available on request from the corresponding author.

Acknowledgments: We are grateful to all participants who took part in the survey.

Conflicts of Interest: The authors declare no conflict of interest.

\section{References}

1. Brabyn, L. Classifying landscape character. Landsc. Res. 2009, 34, 299-321. [CrossRef]

2. Cherrill, A. A comparison of three landscape classifications and investigation of the potential for using remotely sensed land cover data for landscape classification. J. Rural. Stud. 1994, 10, 275-289. [CrossRef]

3. Mucher, C.A.; Klijn, J.A.; Wascher, D.M.; Schaminée, J.H.J. A new european landscape classification (LANMAP): A transparent, flexible and user-oriented methodology to distinguish landscapes. Ecol. Indic. 2010, 10, 87-103. [CrossRef]

4. Romportl, D.; Chuman, T.; Lipsky, Z. Landscape typology of Czechia. Geografie 2013, 118, 16-39. [CrossRef]

5. Miklós, L.; Izakovičová, Z.; Boltižiar, M.; Diviaková, A.; Grotkovská, L.; Hrnčiarová, T.; Imrichová, Z.; Kočická, E.; Kočický, D.; Kenderessy, P.; et al. Atlas of Representative Regions and Types of Landscape in Slovakia Atlas Reprezentativnych Geoekosystémov Slovenska; Ministry of the Environment of the Slovak Republic, Institute of Landscape Ecology of the Slovak Academy of Sciences: Bratislava, Slovakia, 2006; ISBN 80-969272-4-8.

6. Izakovičová, Z.; Miklós, L. Biodiversity Protection of the Forest Ecosystems on the Base of Representative Geoecosystems. In Sustainable Mountain Regions: Challenges and Perspectives in Southeastern Europe-Cham; Koulov, B., Zhelezov, G., Eds.; Springer: Sofia, Bulgaria, 2016; pp. 151-158. ISBN 978-3-319-27903-9.

7. Loh, J.; Harmon, D. A global index of biocultural diversity. Ecol. Indic. 2005, 5, 231-241. [CrossRef] 
8. Council of Europe. Council of Europe Landscape Convention (ETS No. 176). Available online: https://www.coe.int/en/web/ conventions / full-list (accessed on 13 December 2021).

9. Hong, S.-K. Philosophy and background of biocultural landscapes. In Biocultural Landscapes: Diversity, Functions and Values; Hong, S.-K., Bogaert, J., Min, Q., Eds.; Springer: Dordrecht, The Netherlands, 2014; pp. 1-7. ISBN 978-94-017-8941-7.

10. Belčáková, I.; Olah, B.; Slámová, M.; Pšenáková, Z. A cultural and environmental assessment of a landscape archetype with dispersed settlements in Čadca Cadastral District, Slovakia. Sustainability 2021, 13, 1200. [CrossRef]

11. van Oosten, C.J.; Hijweege, W.L. Governing biocultural diversity in mosaic landscapes. In Forest-People Interfaces: Understanding Community Forestry and Biocultural Diversity; Arts, B., van Bommel, S., Ros-Tonen, M., Verschoor, G., Eds.; Academic Publishers: Wageningen, The Netherlands, 2012; pp. 211-222. ISBN 978-90-8686-749-3.

12. Cocks, M.L.; Wiersum, F. Reappraising the concept of biocultural diversity: A perspective from South Africa. Hum. Ecol. 2014, 42, 727-737. [CrossRef]

13. Cocks, M.; Dold, T. Perceptions and values of local landscapes: Implications for the conservation of biocultural diversity and intangible heritage. In Forest-People Interfaces: Understanding Community Forestry and Biocultural Diversity; Arts, B., van Bommel, S., Ros-Tonen, M., Verschoor, G., Eds.; Academic Publishers: Wageningen, The Netherlands, 2012; pp. 167-179. ISBN 978-90-8686-749-3.

14. Agnoletti, M.; Rotherham, I.D. Landscape and biocultural diversity. Biodivers. Conserv. 2015, 24, 3155-3165. [CrossRef]

15. Hutárová, D.; Kozelová, I.; Špulerová, J. Tourism development options in marginal and less-favored regions: A case study of Slovakia's Gemer region. Land 2021, 10, 229. [CrossRef]

16. Baránková, Z.; Dobrovodská, M.; Štefunková, D.; Babicová, D.; Moyzeová, M.; Petrovič, F. Participation of local people on identifying the landscape values and future development in historical agricultural landscapes. Ekol. Bratisl. 2011, 30, 216-228. [CrossRef]

17. Dramstad, W.E.; Tveit, M.S.; Fjellstad, W.J.; Fry, G.L.A. Relationships between visual landscape preferences and map-based indicators of landscape structure. Landsc. Urban Plan. 2006, 78, 465-474. [CrossRef]

18. Roth, M.; Gruehn, D. Visual landscape assessment for large areas-Using GIS, internet surveys and statistical methodologies. Proc. Proc. Latv. Acad. Sci. Sect. A Humanit. Soc. Sci. 2012, 66, 129-142.

19. Roth, M.; Hildebrandt, S.; Röhner, S. Landscape as an area as perceived by people: Empirically-based nationwide modelling of scenic landscape quality in Germany. J. Digit. Landsc. Archit. 2018, 3, 129-137. [CrossRef]

20. Hreško, J.; Petrovič, F.; Mišovičová, R. Mountain landscape archetypes of the Western Carpathians (Slovakia). Biodivers. Conserv. 2015, 24, 3269-3283. [CrossRef]

21. Špulerová, J.; Dobrovodská, M.; Štefunková, D.; Šatalová, B.; Kenderessy, P. The cultural-historical value of traditional agricultural landscape in Slovakia. In Proceedings of the World Heritage and Degradation: Smart Design, Planning and Technologies; Corniello, L., Ed.; Scuola Pitagora Editrice: Napoli, Italy, 2016; pp. 306-315.

22. Supuka, A.; Stepankova, R. Characteristic and marks of cultural landscape of slovakia. Ekol. Bratisl. 2004, 23, 333-339.

23. Podolák. The Atlas of the Slovak Landscape; Hrnčiarová, T., Ed.; Ministry of the Environment of the Slovak Republic: Bratislava, Slovakia, 2002.

24. Oksanen, A.; Guillaume Blanchet, F.; Friendly, M.; Kindt, R.; Legendre, P.; McGlinn, D.; Minchin, P.R.; O'Hara, R.B.; Simpson, G.L.; Solymos, P.; et al. Vegan: Community Ecology Package. Vegan Package. Available online: https://CRAN.R-project.org/ package=vegan (accessed on 10 December 2021).

25. RStudio Team RStudio. Integrated Development for R. RStudio. Available online: https://support.rstudio.com/hc/en-us/ articles/206212048-Citing-RStudio (accessed on 10 December 2021).

26. Statdat. Statistical Yearbook of the Slovak Republic; Statistical Office of the Slovak Republic, VEDA-Publishing House of the SAS: Bratislava, Slovakia, 2020; ISBN 978-80-224-1859-1.

27. Hreško, J.; Kanasová, D.; Petrovič, F. Landscape archetypes as the elements of slovak historical landscape structure. Ekológia 2010 29, 158-173. [CrossRef]

28. Špulerová, J.; Dobrovodská, M.; Lieskovský, J.; Bača, A.; Halabuk, A.; Kohút, F.; Mojses, M.; Kenderessy, P.; Piscová, V.; Barančok P.; et al. Inventory and classification of historical structures of the agricultural landscape in Slovakia. Ekológia 2011, 30, 157-170. [CrossRef]

29. Izakovičová, Z. Evaluation of the stress factors in the landscape. Ekológia 2000, 19, 92-103.

30. Petrovič, F. Changes of the landscape with dispersed settlement. Ekológia 2006, 25 (Suppl. 1), 201-211.

31. EUROBAROMETER. Attitudes of European Citizens towards the Environment. Summary. Survey Requested by the European Commission, Directorate-General for Environment; Directorate-General for Communication: Brussels, Belgium, 2017. Available online: https: / / data.europa.eu/data/datasets/s2156_88_1_468_eng?locale=en (accessed on 13 December 2021).

32. IPBES (Díaz, S.; Settele, J.; Brondízio, E.S.; Ngo, H.T.; Guèze, M.; Agard, J.; Arneth, A.; Balvanera, P.; Brauman, K.A.; Butchart, S.H.M.; et al. (Eds.) Global Assessment Report on Biodiversity and Ecosystem Services of the Intergovernmental Science-Policy Platform on Biodiversity and Ecosystem Services; IPBES Secretariat: Bonn, Germany, 2019. [CrossRef]

33. EEA. The European Environment-State and Outlook 2020-European Environment Agency. Available online: https://www.eea europa.eu/publications/soer-2020 (accessed on 8 December 2021).

34. Masson-Delmotte, V.; Pörtner, H.-O.; Skea, J.; Zhai, P.; Roberts, D.; Shukla, P.R.; Pirani, A.; Pidcock, R.; Chen, Y.; Lonnoy, E.; et al. An IPCC special report on the impacts of global warming of $1.5^{\circ} \mathrm{C}$ above pre-industrial levels and related global greenhouse gas 
emission pathways, in the context of strengthening the global response to the threat of climate change, sustainable development, and efforts to eradicate poverty. In Proceedings of the Intergovernmental Panel on Climate Change, Geneva, Switzerland, 8 January-25 February 2018; p. 630.

35. United Nations. Transforming Our World: The 2030 Agenda for Sustainable Development; United Nations: New York, NY, USA, 2015.

36. European Commission. A European Green Deal. Available online: https://ec.europa.eu/info/strategy/priorities-2019-2024/ european-green-deal_en (accessed on 8 December 2021).

37. European Commission. EU Biodiversity Strategy for 2030. Available online: https://www.eea.europa.eu/policy-documents/eubiodiversity-strategy-for-2030-1 (accessed on 8 December 2021).

38. European Commission. Farm to Fork Strategy. For a Fair, Healthy and Environmentally-Friendly Food System \#EUGreenDeal F. Available online: https:/ / ec.europa.eu/food/horizontal-topics/farm-fork-strategy_sk (accessed on 8 December 2021).

39. Fischer, L.K.; Honold, J.; Cvejić, R.; Delshammar, T.; Hilbert, S.; Lafortezza, R.; Nastran, M.; Nielsen, A.B.; Pintar, M.; van der Jagt, A.P.N.; et al. Beyond green: Broad support for biodiversity in multicultural european cities. Glob. Environ. Chang. 2018, 49, 35-45. [CrossRef]

40. Lieskovský, J.; Rusňák, T.; Klimantová, A.; Izsóff, M.; Gašparovičová, P. Appreciation of landscape aesthetic values in Slovakia assessed by social media photographs. Open Geosci. 2017, 9, 593-599. [CrossRef]

41. van Zeijts, H.; Gerdien Prins, A.; Dammers, E.; Vonk, M.; Bouwma, I.; Farjon, H.; Pouwels, R. European Nature in the Plural Finding Common Ground for a Next Policy Agenda; PBL Netherlands Environmental Assessment Agency, Wageningen University \& Research: Hague, The Netherlands, 2017.

42. Farjon, H.; De Blaeij, A.; De Boer, T.; Langers, F.; Vader, J.; Buijs, A. Citizens' Images and Values of Nature in Europe; A Survey in Nine Member States; PBL Netherlands Environmental Assessment Agency: Hague, The Netherlands, 2016.

43. Arjjumend, $\mathrm{H}$. Recognition of indigenous peoples in access and benefit sharing (ABS) legislation and policies of the parties TO the nagoya protocol. BRICS Law J. 2018, 5, 86-113. [CrossRef]

44. Sibelet, N.; Chamayou, L.; Newing, H.; Montes, I. Perceptions of trees outside forests in cattle pastures: Land sharing within the central volcanic talamanca biological corridor, Costa Rica. Hum. Ecol. 2017, 45, 499-511. [CrossRef]

45. Kizos, T.; Dalaka, A.; Petanidou, T. Farmers' attitudes and landscape change: Evidence from the abandonment of terraced cultivations on Lesvos, Greece. Agric. Hum. Values 2010, 2, 199-212. [CrossRef]

46. Barančoková, M.; Barančok, P. The evaluation of the potential of developing tourism in Kysuce Region. Ekológia 2020, 39, 380-400. [CrossRef]

47. Jim, C.Y. Drivers for colonization and sustainable management of tree-dominated stonewall ecosystems. Ecol. Eng. 2013, 57, 324-335. [CrossRef]

48. Stålhammar, S.; Brink, E. 'Urban biocultural diversity' as a framework for human-nature interactions: Reflections from a Brazilian favela. Urban Ecosyst. 2021, 24, 601-619. [CrossRef]

49. Vierikko, K.; Elands, B.; Niemelä, J.; Andersson, E.; Buijs, A.; Fischer, L.K.; Haase, D.; Kabisch, N.; Kowarik, I.; Luz, A.C.; et al. Considering the ways biocultural diversity helps enforce the urban green infrastructure in times of urban transformation. Curr. Opin. Environ. Sustain. 2016, 22, 7-12. [CrossRef]

50. Považan, R.; Filčák, R.; Kadlečík, J.; Chrenko, M.; Orfánus, T. Use of scenario approach in the environment based on short-term scenarios for biodiversity and climate change by 2020. (In Slovak: Využitie Scenárového Prístupu v Životnom Prostredí Na Príklade Krátkodobých Scenárov Do Roku 2020 v Oblasti Biodiverzity a Zmeny Klímy). Zivotn. Prostr. Rev. Pre Tóriu Starostlivost' O Zivotn. Prostr. 2019, 53, 91-101.

51. Filčák, R.; Považan, R.; Adamec, M.; Dokupilová, D.; Chrenko, M.; Izakovičová, Z.; Kadlečík, J.; Szemesová, J.; Špulerová, J.; Št'astný, P. Development Scenario in Environment up to 2020+. Sustainable Development, Biodiversity and Climate Changes. In Slovak: Scenáre Vývoja v Životnom Prostredí 2020+. Udržatel'ný Rast, Biodiverzita a Zmeny Klímy; Centrum Spoločenských a Psychologických Vied, Slovenská Akadémia Vied: Bratislava, Slovakia, 2017.

52. Považan, R.; Filčák, R.; Chrenko, M.; Mederly, P.; Špulerová, J.; Ivanegova, B.; Kadlečík, J.; Kapusta, P.; Gusejnov, S.; Švajda, J.; et al. Nature Outlook 2050: Scenarios for Nature in Slovakia and Implications for Public Policies [Scenáre Pre Prírodu Na Slovensku a Ich Implikácia do Verejnej Politiky]; Ministry of the Environment of the Slovak Republic, Slovak Environment Agency: Bratislava, Slovakia, 2020; ISBN 978-80-8213-012-9. 